\title{
Many Nationalisms, One Disaster: Categories, Attitudes and Evolution of Chinese Nationalism on Social Media during the COVID -19 Pandemic
}

\author{
Zhenyu Wang $^{1}$ (D) Yuzhou Tao ${ }^{1}$
}

Accepted: 25 January 2021/ Published online: 24 March 2021

(C) Journal of Chinese Political Science/Association of Chinese Political Studies 2021

\begin{abstract}
Previous research has shown the increase of Chinese nationalism in some international events. However, it is unclear how a specific event fosters the rise of a particular type of nationalism, and how these different categories of nationalism relate to globalism. Given that, this study collected the most popular comments on 164 international COVID-19 events on Weibo to categorize different types of nationalism and measure the popularity index. The distribution of nationalism-categories across different topics was later estimated through semantic analysis, so as to explore how nationalism implies netizens' anti-globalization and pro-globalization sentiments. Specifically, the study categorized two different expressions of nationalism during the COVID-19 pandemic in China: a counterattack posture to external threats that is reflected as the Suppression of Ambivalent Attitudes, or a comparative response to global competition that serves as a stimulate to the Feeling of National Superiority. While the first expression is aligned with anti-globalization feelings, the second nationalistic sentiment stems from a sense of national superiority, which does not pose a threat to globalization. Our research revealed that a political global crisis not only influences the rise of nationalism but also its evolution.
\end{abstract}

Keywords COVID-19 pandemic · Chinese nationalism - Globalization - Global disaster · Social media

\section{Introduction}

The COVID-19 pandemic raises a fundamental question: Is this a point in time when the world will permanently change? Is this "the end of globalization as we know it"?

Zhenyu Wang

zhenyuwang18@fudan.edu.cn

1 Fudan Journalism School, 400 Guoding Rd, Shanghai 200433, China 
With the infection of more than two million people worldwide, as well as large-scale blockades, suspensions, curfews, and rising unemployment, the world is experiencing a critical conjuncture in human history that has evolved from a public health crisis to an economic and political crisis. Pessimists believe that this event will lead to closures, authoritarianism, and divisions due to panic, shortage, and inequality. The epidemic is believed to have shaken the foundation of the current liberal international order and provided opportunity for the authoritarian sub-order [22, 44]. In the words of Stephen Walter, the COVID-19 pandemic will create a less open, less prosperous, and less free world [4]. However, some optimists believe that because COVID-19 is a common enemy of all mankind, it will provide new opportunities for global governance. It is fundamental that the new global order is built on multilateral cooperation, since no country can deal with the virus alone. The centralist believes that a worldwide epidemic will trigger the transformation of the world economy, including the enhancement of regionalization and the rise of new international trade norms, but the final result remains uncertainty $[3,76]$.

In both these predictions of the post-pandemic world, nationalism is regarded as the most important factor in making changes to the global order. First, the logic of nationalism is how people perceive the impact of the virus in the first place. At the beginning of the outbreak, the government's anti-epidemic policies and media reports tended to strongly support national medical priorities, without considering the potential external costs or impacts, and even called for reducing international cooperation to deal with the shortage of masks and other medical supplies. This "medical nationalism" constituted the initial recognition of, and response to, the pandemic [80]. For a supranational institution such as the EU, the coordination problems caused by nationalism further weaken its ability to act [65]. Second, nationalism is considered to be closely linked to, and strengthened by, authoritarianism, populism, and antiglobalization [12]. A dangerous pandemic could lead to a state of emergency, which is the core of authoritarianism and dictatorship. On the one hand, individuals are more inclined to give up part of their freedom and undermine the sovereignty under the principle of liberalism [58]. On the other hand, far-right and populist politicians are also willing to consolidate their power by inciting nationalist sentiment. For example, Trump insisted on calling this new coronavirus a "Chinese virus" and tweeted "This is why we need borders!" on March 23rd. ${ }^{1}$ In addition, nationalism has caused further turbulence in existing international order. Nationalism regards the nation-state as the most decisive political unit and prefers national loyalty in politics ([10]:10). Therefore, many forecasts believe that the rise of nationalism due to the pandemic will be the force that ends globalization. Last but not the least, the Internet and social media has accelerated nationalism, which has now become everyday political practice [38]. Although the development of ICT technology has provided the possibility of establishing a global public space, the Internet and new media have also become catalysts for nationalism [31]. During the pandemic, the WHO emphasized that the rapid spread of

\footnotetext{
${ }^{1}$ See on CNN. 2020. "Photo shows 'corona' crossed out and replaced with 'Chinese' in Trump's briefing notes," 19 March. Available at: https:/edition.cnn.com/world/livenews/coronavirus-outbreak-03-19-20-intlhnk/h_21c623966aa148dbeed242de4e94943e. (Accessed April 9, 2020). Trump, Donald J. (@realDonaldTrump) 2020. “THIS IS WHY WE NEED BORDERS! Tweet, 23rd March, 15.16. Available at https://twitter.com/realDonaldTrump/status/1242092738973249536 (Accessed April 9th, 2020).
} 
misinformation may have a negative impact on social media [53], and the spread of such misinformation can also easily lead to ideological polarization [71].

China's nationalism is central to the debate on global order in a post-pandemic world. In the pandemic period, anti-Chinese comments and sentiments have exploded on social media worldwide, whereby Chinese people have become scapegoats for viral disasters [28]; such disrespect and distrust are regarded as the most important external origin of Chinese nationalism[63]. Simultaneously, Chinese nationalism is considered to be an important influencing factor in China's foreign policy. However, for nationalism and other ideologies, this crisis is a competing field to advance their political agenda [75]. Before any predictions are made on the impact of Chinese nationalism on world order, there are at least three theoretical questions that need to be answered. First, how will global disaster affect Chinese nationalism? Owing to the rarity of global natural disasters, the existing literature on external causes of the rise of Chinese nationalism are more focused on international conflicts and political manipulations $[42,84,16]$ and few empirical explanations of the consequences of global disasters exist. Second, how was Chinese nationalism constructed in the context of social media? The rise of mass media is considered to be an important factor in the rise of nationalism, and it is "print capitalism" that constitutes the "imagined community." ([6]:39) However, in the more personalized environment that exists on social media [57], how does the complicated Chinese nationalism show its face? Is it pro- or anti-government? Is it benign internationalism or exclusive racism? Finally, is nationalism really the end of globalization? Although many studies have pointed out the threat of nationalism to global order, some studies also state that Chinese nationalism has a positive position in terms of enhancing its international status by participating in global governance [89]. China's active international medical assistance activities during this period is another problem that needs to be resolved.

\section{Literature Review: Chinese Nationalism in a Global Disaster}

\section{Rethinking Contemporary Chinese Nationalism}

Although the nationalist identity points to a long period of nature and history, its origin, which occurred after the birth of the European nation-state, is relatively recent. As the most dynamic and mobilizing ideology today, nationalism has multiple connotations. It usually includes a sense of belonging, honor, and close connection to the nation ([43]:1). In the existing literature, the theory of nationalism emphasizes at least three aspects; first, nationalism is composed of a series of identities based on historical symbols. For example, Smith believes that most countries have deep-rooted historical roots, including ancestry, culture, and common history ([70]:25, 50). These symbols are often linked to ethnic and cultural characteristics, and profoundly affect the composition of the core unit of modern international politics - the nation-state [56, 73]. Second, nationalism includes the definition and defense of a political boundary. As Anderson defined the nation as an imagined political community with borders and sovereignty, nationalism contains at least a political and cultural identity based on distinction and comparison([6]:3172). Even if it does not produce xenophobic racism as Balibar and Wallerstein believed ([8]:37, 217), it does express a constantly changing relationship 
between "us" and "them," while also presenting a competitive field that responds to the outside world[30]. Third, nationalism has functional characteristics. In Gellner's pioneering research on nationalism, he proposed that economic development generated the need for unified knowledge through standardized education. Therefore, a highly homogeneous culture of nationalism can effectively promote the development of modernization ([35]:64). Following this functionalist approach, subsequent researchers also discussed the role of nationalism in maintaining and consolidating the legitimacy of the existing political order $([15,41])$, especially as a tool used by the elite to maintain political power in the face of internal or external pressure[81].

These three aspects present an extremely complicated state in the development of Chinese nationalism. Most importantly, the identity resources of the Chinese nation are extremely complex in terms of time and content. This can be traced back to the glorious history of the Han and Tang dynasties thousands of years ago and also includes the memory of national shame as a result of being invaded by Western powers throughout the past century [20]. After the reform and opening up, consumer culture and Marxism have also become important resources for the construction of Chinese nationalism [74]. This contradictory combination stems from a common psychological foundation: the pride of an idealized country constitutes a political identity, and the external reason is the synchronization of China's rise and globalization ([45]:92). As the connection to the global capitalist world system deepens, China needs to readjust its relationship with other major powers in the world. Its core appeal includes gaining recognition of its strength and status ([88]:8). Simultaneously, along with the memory of powerful dynasties and victorious revolutions, China's strength in international events such as the Olympic Games and the World Expo also forms part of the national honor [79]. In this case, everything from geopolitical conflict to unrecognition in the international media is regarded as an offense to China, which, in turn, has become a callable resource for nationalism ([69]:79).

In this sense, nationalism in contemporary China is a reaction of international events [85], particularly a passive response to new global competition. However, this passive logic also lies in the functional change of nationalism. After Sun Yat-sen and Deng Xiaoping's political elites succeeded in using nationalism to establish modern China and maintain the legitimacy of the regime $[39,84]$, China's nationalism gradually evolved away from the elite's control and showed a spontaneous trend. The representative event is a national bestselling book called "China Can Say No," which criticizes the government for being too weak in foreign policy [32]. With the advent of the Internet, popular nationalism has become more common. National emotions and collective memories that were depressed for a long time have not been reduced by changes in the expressing field but have been continuously strengthened. The online nationalist movement has always been accompanied by fierce discourse confrontation and "radical electronic resistance"([77]:185). These spontaneous comments on social media have led to further dissatisfaction with the existing regime's handling of international affairs [82]. This kind of nationalism is not so much the outcome of the elite's manipulation of the regime's legitimacy and diplomatic goals, but rather the venting and expression of popular emotions.

\section{Chinese Nationalism after the Pandemic}

The global pandemic constitutes a new round of stimulation for Chinese nationalism. In a few discussions on the impact of global disasters on nationalism, Bieber [10] regards 
the state of emergency, prejudice, anti-globalization border closures, and fears caused by disasters as the main channels for stimulating the rise in nationalism. As the country with the earliest outbreak, China has almost entirely experienced these four influences, especially in terms of prejudice, as serious anti-Chinese and anti-Asian incidents have occurred in the United States, Europe, and Australia. ${ }^{2}$ Under the pressure of uncertainty and insecurity brought about by the crisis, nationalism has further exacerbated China's tense diplomatic relations with these countries, which is reflected in increasingly fierce frictions such as trade wars and narrative wars [13, 47, 62]. Given the victim memory of Chinese nationalism, this is undoubtedly an enormous stimulus, although the pandemic also constitutes global competition. By prompt central response and coordination, China has more effectively controlled the epidemic by identifying, tracking, quarantine and restricting population movement. That indicate the success of China's governance model and are even considered by Fukuyama as the key to the transfer of world leadership in the post-epidemic era [2, 33, 83]. Compared with the United States and Europe, China controlled the epidemic relatively swiftly after the outbreak. This caused the global disaster to inspire Chinese nationalism in the "winner" dimension. With the development of globalization and political changes, competing for normative leadership in global governance has become a fiercely competitive area of discourse and discussion [14]. As the main international competition entity, the state's outstanding performance in economic, political, and cultural terms constitutes an important source of nationalism $[26,54]$. People may be more inclined to understand the state as a mere competitive entity from an international perspective, rather than as a victim in need of defense.

Given the rarity of this global disaster, the existing literature has rarely explored its impact on nationalism. However, the huge exogenous crisis and social response caused by global disasters often constitute a "critical juncture." The institution and policy path being chosen at this moment are difficult to change under normal circumstances, which makes it necessary to pay attention to its impact on Chinese nationalism. Many studies state that contemporary Chinese nationalism reflects the public's response to China's setbacks in the process of globalization (such as China's sovereignty, territorial integrity, and identity, etc.), and advocates improving China's international status [7, 40, 55]. However, from the perspective of the psychological mechanism of nationalism, this kind of psychological structure, with identification at its core, is not onedimensional [17, 21, 50]. Its diversity includes not only constructive patriotism and nationalism from a critical perspective but also the diversities within nationalism, such as idealization of the nation, derogation of non-ethnic groups, and uncritical support for the state and political authority [11]. Studies on Chinese official and online discourse during the epidemic has further revealed its complexity: they show not only globalism,

\footnotetext{
${ }^{2}$ See CNN. 2020. "Photo shows 'corona' crossed out and replaced with 'Chinese' in Trump's briefing notes," 19 March. Retrieved from: https:/edition.cnn.com/world/live-news/coronavirus-outbreak-03-19-20-intl-hnk/ h 21c623966aa148dbeed242de4e94943e. (Accessed April 9th, 2020). Escobar, Natalie. 2020. "When Xenophobia Spreads Like A Virus,” NPR Code Switch, 4 March. Available at https://www.npr.org/2020/ 03/02/811363404/when-xenophobia-spreads-like-a-virus? $\mathrm{t}=1585605937840 \& \mathrm{t}=1585738440331$. (Accessed April 9th, 2020).; FRA (Fundamental Rights Agency). 2020. Coronavirus Pandemic in the EU-Fundamental Rights Implications. Bulletin 1, 1 February-20 March 2020, 7 April. Retrieved from: https://fra.europa.eu/sites/default/files/fra_uploads/fra-2020-coronavirus-pandemic-eu-bulletin-1_en.pdf. (Accessed April 8th, 2020).
} 
rational and confident, but also nationalism, vigilance and even hostile [78, 87]. However, in the existing literature on Chinese nationalism, few studies have provided empirical evidence on what kind of nationalism different types of external stimuli will produce; these studies also rarely determine the relationships between different kinds of Chinese nationalism and globalization. Obviously, the idealization of nations and the derogation of non-ethnic groups will lead to considerably different attitudes toward the current global order.

\section{Theoretical Perspectives and Research Questions}

As a global crisis, the COVID-19 pandemic not only deepened the importance of investigating the diversity and evolution of Chinese nationalism, but also provided empirical data for relevant research on social media. By using comments to international COVID-19 events on social media, this article attempts to answer the following four questions about Chinese nationalism and its relationship with globalization.

First, Chinese nationalism is a hybrid of universal political psychology and unique political experience, stemming from the pride of an idealized country which constitutes the identification of political identity, synchronized with China's rise and globalization ([45]:92). If Chinese nationalism is a passive response to international events, before answering the implications of Chinese nationalism for the global community, we must figure out the following research question (RQ1):

RQ1: Whether and how did the issue-topics of international COVID-19 events influence the categories of Chinese nationalism?

On the other hand, based on previous argument that Chinese nationalism is a reactive response to external stimulation, the evolution of Chinese nationalism as the pandemic develops is also our subject of interest, especially considering that the epidemic has been contained in China and got worse in other countries. Hence, the second RQ was proposed.

RQ2: Did Chinese nationalism fluctuate with the development of COVID-19? If so, how did each category of Chinese nationalism change during this period?

Prior research pointed out that nationalism regarded the nation-state as the most important political unit $[10,59,86]$. This research attempts to examine the applicability of this argument to Chinese nationalism and how it unfolds on social media during the COVID-19 outbreak. In this respect, the semantic networks of social media content proffer a lens for inquiries into how the public thinks and feels. Hence, we raised RQ3:

RQ3: What is the discourse of the most significantly highest categories of Chinese nationalism to COVID-19 pandemic by semantic networks?

Nationalism is also considered to be linked to and strengthened by authoritarianism, populism and anti-globalization [12]. Some scholars argued that by removing boundaries, globalization constitutes a threat to the maintenance of nation-states, which is the ultimate aim of nationalism [9]. That work in concert with one aspect of nationalism 
that is the suppression of ambivalent attitudes toward the nation [1, 64]. Other scholars, like Giddens, stated that "the nation-state is not disappearing, and the scope of government, taken overall, expands rather than diminishes as globalization proceeds ([36:32])." With regard to China, one of the primary winners of globalization [34], its nationalism does not necessarily oppose globalization but instead tends to emphasize its superior position in the current international order. Given that nationalism could also be characterized by a feeling of national superiority [48, 52], it's probable that Chinese nationalism would give raise to positive attitudes to globalization. To figure out the relationship between Chinese nationalism and globalization, RQ4 and 3 hypotheses were formulated as:

RQ4: How was attitudes to globalization related to Chinese nationalism during the period of COVID-19 pandemic?

H1: Chinese nationalism is more likely to be stimulated in a pro-globalization context than an anti-globalization context.

H2: Chinese nationalism that emphasizes suppression of ambivalent attitudes toward the nation give raise to anti-globalization.

H3: Chinese nationalism that emphasizes nation's superiority contribute to attitudes of pro-globalization.

\section{Method}

\section{Data}

\section{COVID-19 Issues}

Based on the event library established in a database that monitors hot social events in China, named ZHWEIDATA (where the criteria for inclusion is high transmission in a short time, a certain amount of transmission over a long period of time, or causing hot discussion on social media), ${ }^{3}$ we collected information on 158 international events concerning COVID-19 (labeled "epidemic," "coronavirus," or "pneumonia"). As nationalism is mostly aroused and expressed in terms of international political and economic issues, other categories of events (like domestic events and sport or entertainment events) were removed from our dataset. Additionally, we added seven events that were also discussed on social media but not selected as part of the library. One other event that belonged to domestic events but was misclassified into international events by ZHWEIDATA was also excluded. After these steps, the dataset consisted of 164 international COVID-19 events that discussed China.

\section{Weibo Posts and Comments}

To measure public opinion on nationalism, we collected original data of international events related to COVID-19 from social media. We focused on social media due to its

\footnotetext{
3 These data can be accessed at https://ef.zhiweidata.com/library
} 
prevalence as a primary place for expressing public opinion, as well as the fact that natural discourse on social media is closer to reality than information collected through surveys and experiments. Social media data used in this research were collected from a popular Chinese microblog platform, Weibo. Weibo is strikingly similar to Twitter in the western world and had over 462 million monthly active users in 2018 . $^{4}$ Weibo does not provide public API access to its database, and the output of the keywords-based advanced search of Weibo posts (via its web interface) is limited to 50 pages (1000 newest posts). This makes access to large-scale public data difficult. Therefore, we chose popular posts from each event as a potential source of content for this study. This is significant in that popular posts tend to have more comments and reposts, which can be used to explore the characteristics of nationalism expressed by the public.

We retrieved COVID-19 posts by searching all the most popular posts of each event through a keywords-based advanced search, with a list of combination of keywords (e.g., "America AND unemployment," "Ma Yun AND Iran AND mask"). After removing duplicates (i.e., posts belonging to more than one event), we retained 15,830 popular posts sent between December 30, 2019 (i.e., the official confirmation date of COVID-19) and May 31, 2020. To make our data more focused, we eliminated posts with less than 100 comments and were left with 4210 posts.

Following this, we collected the comments from the 4210 posts obtained from Weibo. Owing to the platform's restrictions, crawling all the comments on a post was difficult, so we did our best to collect the top 380 comments from each post. In addition, we focused on top comments (ranked by number of likes and replays), as they represent more attention and approval, therefore meeting our research purpose. After these steps, our corpus included 689,450 comments from the 4210 Weibo posts.

\section{COVID-19 Daily Case Counts}

We collected daily case counts in Mainland China from China CDC on June 29, 2020. China CDC's official website started collating data from January 16, 2020. The global daily case counts were collected from the John Hopkins University's Coronavirus Resource Center which collated from January 22, 2020. To acquire daily case counts from abroad, we subtracted daily new case counts of China from those worldwide.

\section{Measurement}

\section{Features of Events}

Topic This study aims to characterize the nationalism aroused and expressed on issues concerning COVID-19, which became heated discussions on social media, and explore how their discourse related to the nation and globalization. After reading the brief introduction of events provided by ZHIWEIDATA, and based on their familiarity with all 164 events, two researchers extracted 9 topics: Diagnosis of Foreign Elites, Outbreaks in Other Countries, Mitigation Strategies of Foreign Countries, Consequences of Epidemic in Other Countries, China's Response to Virus Importations, China's

\footnotetext{
${ }^{4}$ Sina. 2018 Annual Sina Weibo User Report. 2019. Accessed from: https://data.weibo.com/report/ reportDetail?id=433.
} 
Participation and Assistance in International Governance, Criticism of China, COVID19 Bonding the Entire Human Community, and Issues Involving Territory or Sovereignty.

\section{Nationalism}

Categories Though Nationalism is difficult to quantify due to its imprecise definition, previous works tended to characterize Nationalism by the following aspects: (1) The suppression of ambivalent attitudes toward the nation [1]; (2) A feeling of national superiority [52]; (3) An inclination to define one's own group by criteria of descent, race, or cultural affiliation [5]; (4) Derogation of groups not considered to be part of the nation [67]; (5) Idealization of the nation [1]; and (6) An uncritical acceptance of national, state, and political authorities ([1, 61]; Blank, Thomas and Schmidt [11] summed these aspects and differentiated nationalism and patriotism. These descriptions are widely quoted and approved in recent research [18, 27, 60].

Based on these characteristics, we divided our three main categories into six components, and developed a coding instrument (Table 1).

According to the coding scheme, four research assistants (RAs) manually classified 5046 of the most popular comments (those with more than 500 each of likes and comments) in our dataset. The intercoder reliability, based on 300 overlapping comments, met or exceeded conventional standards of agreement (Krippendorff's $\alpha=0.91$ ). The reason why we chose comments from ordinary netizens to measure nationalism is its truly repetitive of public opinion. They were different from other posts in corpus that were news briefs released by media accounts but only present facts and have high levels of plagiarism. Although there are 689,450 comments in our dataset, manually coding such a big corpus would have been a huge challenge. Moreover, Weibo comments are generally as short as a word and contain a lot of cyber language and emojis that are difficult to identify, so we dropped using supervised machine learning and chose hand coding to classify these 5046 most representative comments.

Popularity Index To construct the popularity index of nationalism, we chose the number of "Like" to represent the degree of nationalist emotion on social media. "Like" signifies other user's favor or agreement with a specific comment, which shows its popularity. Based on the Classification of Nationalism, we calculated the popularity of each category per day by adding together all "Likes" in the corpus on that day.

\section{Globalization}

Finally, we coded the globalization feature of these 164 events and the attitudes to globalization in comments which exhibited Suppression of Ambivalent Attitudes toward the Nation and Feeling of National Superiority. As our research purpose was to test the relation of pro- or anti-globalization with nationalism, we only classified the attitudes to globalization into three categories: anti-globalization, pro-globalization, and neutral.

Globalization is the transformation of the spatial organization of social relations and transactions ([49]:55). Steger [72] put forward six core claims to summarize multiple 
Table 1 Coding instrument (nationalism)

\begin{tabular}{ll}
\hline Category of nationalism & Individual components \\
\hline $\begin{array}{l}\text { 1. The suppression of ambivalent } \\
\text { attitudes toward the nation }\end{array}$ & $\begin{array}{c}\text { Suppress ambivalent } \\
\text { attitudes toward the } \\
\text { nation within the country }\end{array}$ \\
$\begin{array}{c}\text { Counterattack to negative } \\
\text { evaluation or insulting } \\
\text { behavior of the West }\end{array}$
\end{tabular}

2. Feeling of national superiority

3. Inclination to define one's own group by criteria of descent, race, or cultural affiliation

\section{Derogation of groups not} considered part of the nation

5. Idealization of the nation

6. An uncritical acceptance of national, state, and political authorities

7. Other (have nationalist tendency but can't be classified into the above categories)

8. None (no any nationalist feature)

Being proud of the nation
Criticize and mock other countries Comparing to China

Indifference toward difficult situation in other countries

Refuse to share resources with people from other countries
Examples

"The whole dairy relies on hearsay. She defamed the Chinese government's devoted effort to fighting the epidemic with her dark side"

"As a Chinese person, I feel very angry and Denmark must apologize"

"American flu! American H1N1!"

"Compared with other countries, China controlled the transmission of COVID-19 in less than a month. No other country could heal people free of charge like us. Our powerful backing, China!"

"They copied the work of the Chinese government, which proves that the Chinese government is so powerful and has gained all the nation's worship"

"More than 100,000 deaths couldn't wake up a president who only cares about dollars, nor can it move a government that only wants capital"

"Soaring confirmed case numbers may be due to herd immunity"

"It turns out that white people are more suitable for virus transmission"

"This good boy, living in a foreign country, had Chinese traditional culture in his mind and encouraged compatriots overseas with ancient poems"

"Great America! It has completed the task of 1 million confirmed cases ahead of schedule"

"More and more people are infected. Will tomorrow be more wonderful?"

"It must be segregated in accordance with rules. Welcome compatriots, not foreigners"

Denmark, don't grab the reputation of China!

Why not severely punish those people who complain that they have no human rights when returning to China?

"She is a student studying abroad at the state's expense but supports Hong Kong's independence and Taiwan's service trade agreement" 
attitudes towards globalization: (1) Globalization is about the liberalization and global integration of markets; (2) Globalization is inevitable and irreversible; (3) Nobody is in charge of globalization; (4) Globalization benefits everyone; (5) Globalization furthers the spread of democracy in the world; (6) Globalization requires a war on terror. Relevant research usually adopted these six propositions to support/anti-globalization $[24,66,68]$.

Based on the claims of Steger and the context of pandemic, after consulting relevant Political, Journalism and International relations scholars, we put forward four aspects to distinguish different attitudes toward globalization: (1) Criticism of the global allocation of medical resources reflects anti-globalization sentiment; (2) Trust attitudes toward the existing global organization and institution reflects the preference for globalization; (3) Whether the attitudes support China's undertaking of international responsibilities; (4) Whether They believe individuals, groups or countries could benefit from globalization.

The coding instrument of globalization is found in Table 2:

\section{Semantic Network Analysis}

Semantic network analysis was conducted to address the RQ3 regarding the discourse of the most significantly highest categories of Chinese nationalism to COVID-19 pandemic. In a semantic network, word-use frequencies and co-occurrence of the most frequently occurring words represent shared meanings and common perceptions in people's minds [29]. To answer RQ3, we analyzed the content of the comments to calculate the frequency of words and determine the most frequently co-occurring word pairs using Python3.8. Each individual comment was a unit of analysis, with word frequency defined as the times the word appeared and word pair co-occurrence was defined as the appearance of two words in the same comment. When the data were loaded into the program, a word frequency table (node) and a word co-occurrence network (edge) were generated. The visualization of the semantic networks was accomplished using Ggephi0.9.2. To be included in the final semantic network, a word or multiword phrase must have appeared in more than $1 \%$ of comments [25].

\section{Empirical Analysis}

\section{Nationalism-Categories Distribution Across Issue-Topics}

The key substantive question we want to answer is whether the issue-topics events stimulate nationalism and influence their categories. If so, we also sought to determine whether each category of nationalism is stimulated by particular issue-topics.

Table 3 presents the proportion of each nationalism-category in the 5046 most popular comments from the corpus. The Suppression of Ambivalent Attitudes toward the Nation and Feeling of National Superiority made up the largest proportions.

We used a Chi-square test to study the difference between issue-topics and different categories of nationalism. Issue-topics showed a 0.01 level of significance for nationalismcategories $\left(\chi^{2}=3292.497, P=0.000<0.01\right)$. Figure 1 displays the percentage distribution of categories across various topics. The salient expression of nationalism includes The 
Table 2 Coding instrument (globalization)

Attitude towards Individual components globalization

\begin{tabular}{|c|c|c|c|}
\hline \multirow[t]{4}{*}{ Pro-globalization } & $\begin{array}{l}\text { Support global allocation of } \\
\text { medical resources }\end{array}$ & $\begin{array}{l}\text { Jack Ma raises } 1 \\
\text { million masks } \\
\text { for Iran }\end{array}$ & $\begin{array}{l}\text { In this special period, we should } \\
\text { unite tightly and help each } \\
\text { other! }\end{array}$ \\
\hline & $\begin{array}{l}\text { Support existing global } \\
\text { organizations and institutions }\end{array}$ & $\begin{array}{l}\text { The Chinese } \\
\text { government } \\
\text { donates } \$ 20 \\
\text { million to WHO }\end{array}$ & $\begin{array}{l}\text { Thank you WHO! Since the } \\
\text { outbreak of the epidemic, they } \\
\text { have been helping us deal with } \\
\text { many unkind suggestions and } \\
\text { malicious slanders }\end{array}$ \\
\hline & $\begin{array}{l}\text { Proud of China's international } \\
\text { actions }\end{array}$ & & $\begin{array}{l}\text { "Praise for such behavior. } \\
\text { China's international status is } \\
\text { much higher" }\end{array}$ \\
\hline & $\begin{array}{l}\text { Globalization has increased } \\
\text { political, economic and social } \\
\text { interests }\end{array}$ & $\begin{array}{l}\text { The G20 will } \\
\text { launch a } \$ 5 \\
\text { trillion } \\
\text { economic boost } \\
\text { plan }\end{array}$ & $\begin{array}{l}\text { When the disaster strikes, the } \\
\text { whole world is one family } \\
\text { Welcome to join the Belt and } \\
\text { Road strategic cooperation and } \\
\text { hope that more countries will } \\
\text { join }\end{array}$ \\
\hline \multirow[t]{4}{*}{ Anti-globalization } & $\begin{array}{l}\text { Oppose global allocation of } \\
\text { medical resources }\end{array}$ & $\begin{array}{l}\text { Germany } \\
\text { intercepts Swiss } \\
\text { imports of } \\
\text { protective } \\
\text { masks }\end{array}$ & $\begin{array}{l}\text { Visually, European countries are } \\
\text { about to start a war of mask }\end{array}$ \\
\hline & $\begin{array}{l}\text { Oppose existing global } \\
\text { organizations and institutions }\end{array}$ & $\begin{array}{l}\text { Trump says he is } \\
\text { considering } \\
\text { stopping } \\
\text { funding for } \\
\text { WHO }\end{array}$ & $\begin{array}{l}\text { The G20 economic plan will lead } \\
\text { to the inevitable global } \\
\text { inflation }\end{array}$ \\
\hline & $\begin{array}{l}\text { Dissatisfied with China's } \\
\text { assistance to foreigners or } \\
\text { dissatisfied with China's } \\
\text { support for global flows }\end{array}$ & & $\begin{array}{l}\text { Why not serving the Chinese like } \\
\text { foreigners? } \\
\text { Guard the country, prevent the } \\
\text { import of new crowns, and } \\
\text { prevent capital infiltration }\end{array}$ \\
\hline & $\begin{array}{l}\text { Globalization has decreased } \\
\text { political, economic and social } \\
\text { interests }\end{array}$ & $\begin{array}{l}\text { New imported } \\
\text { confirmed cases } \\
\text { from Italy found } \\
\text { in Zhejiang }\end{array}$ & $\begin{array}{l}\text { What is it about the people? What } \\
\text { can the people do? Wear } \\
\text { mask? What else? Our life } \\
\text { can't recover }\end{array}$ \\
\hline
\end{tabular}

Examples (events) Examples (comments) ck Ma raises million masks

Chinese donates $\$ 20$

G20 will economic boos plan

rmany imports of protective rump says he is sidering this special period, we should unite tightly and help each

hank you WHO! Since the outbreak of the epidemic, they have been helping us deal with many unkind suggestions and

Praise for such behavior. China's international status is hen the disaster strikes, the elcome to join the Belt and hope that more countries wil sually, European countries are

roud of China's international political, economic and social

ppose existing globa assistance to foreigners or dissatisfied with China's

lobalization has decreased political, economic and social from Italy found

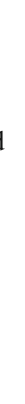

(


Table 3 General distribution of nationalism-categories

3. Inclination to define one's own group by criteria of descent, race, cultural affiliation

4. Derogation of groups not considered to be part of the nation

5. Idealization of the nation

6. Uncritical acceptance of national, state, and political authorities

7. Other

Total

Suppression of Ambivalent Attitudes toward the Nation was more likely to emerge in comments about China's response to virus importations.

In addition, consequences of epidemic in other countries and the identification with human community being bonded in COVID-19 to the entire were likely to arouse expressions with no nationalist emotion, the proportion of which was $66.83 \%$ and $59.82 \%$.

\section{Evolution of Nationalism as the COVID-19 Epidemic Developed}

Figure 2 displays the evolution of each category of nationalism in our social media corpus as the COVID-19 epidemic developed (up until May 31st, 2020). The

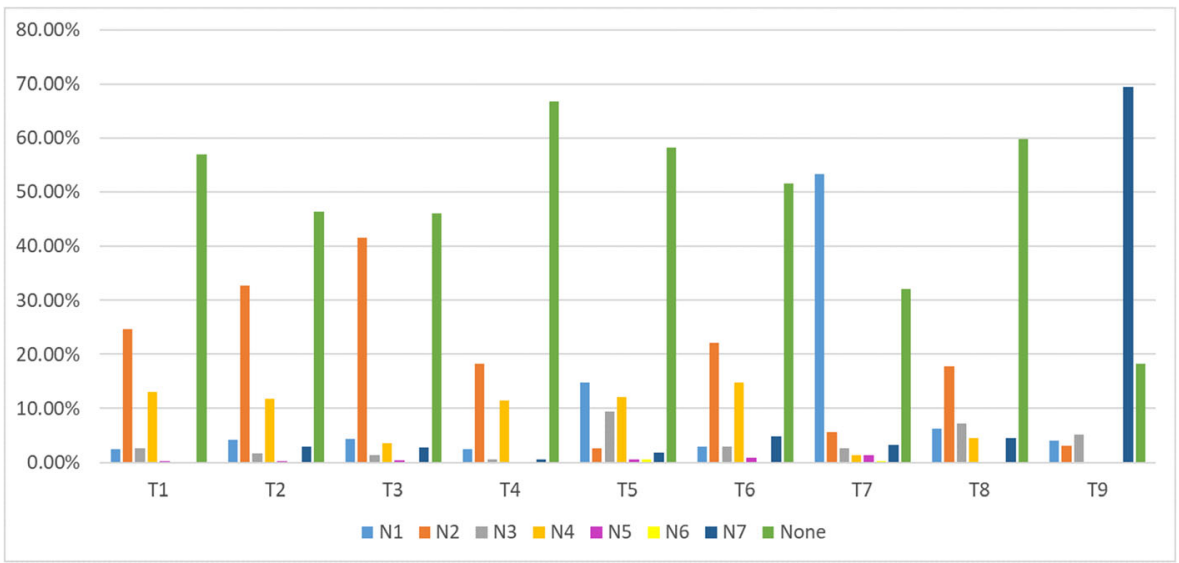

Fig. 1 Percentage distribution of nationalism categories across topics. (Figure 1 note: T1 = Diagnosis of Foreign Elites; T2 = Outbreaks in Other Countries; T3 = Mitigation Strategies of Foreign Countries; T4 = Consequences of Epidemic in Other Countries; T5 = China's Response to Virus Importations; T6 = China's Participation and Assistance in International Governance; T7 = Criticism of China; T8 = COVID-19 Bonding the Entire Human Community; T9 = Involving Territory or Sovereignty. N1 = The Suppression of Ambivalent Attitudes toward the Nation; N2 = Feeling of National Superiority; N3 = Inclination to Define One's Own Group by Criteria of Descent, Race, Cultural Affiliation; N4 = Derogation of Groups Not Considered to Be Part of the Nation; N5 = Idealization of the Nation; N6 = An Uncritical Acceptance of National, State, and Political Authorities; N7 = Other.) 


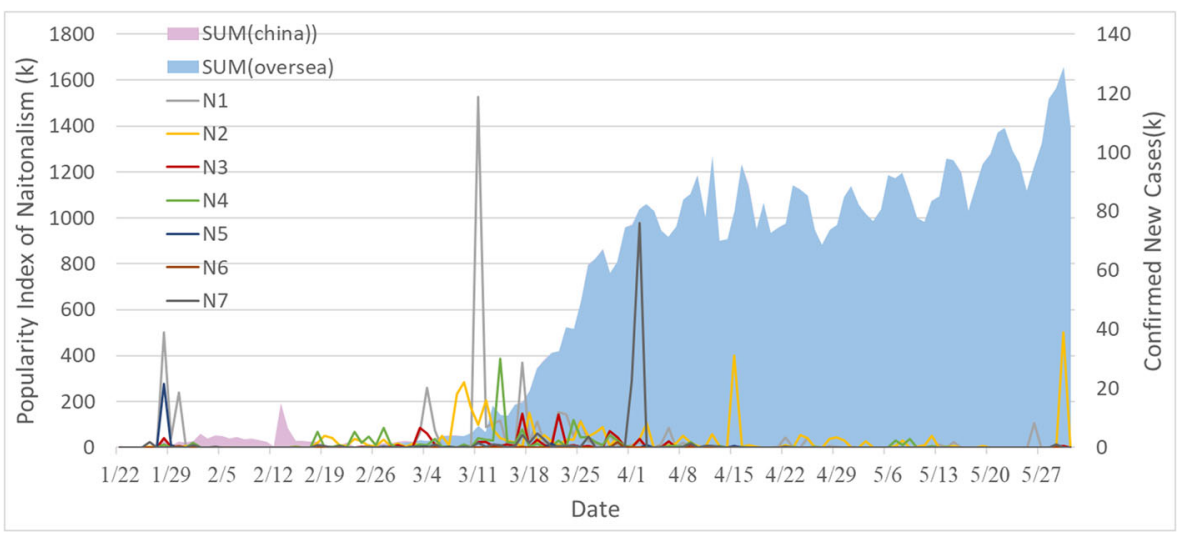

Fig. 2 Evolution of nationalism as epidemic of COVID-19 developed. (Figure 2 notes: N1 = The Suppression of Ambivalent Attitudes toward the Nation; N2 = Feeling of National Superiority; N3 = Inclination to Define One's Own Group by Criteria of Descent, Race, Cultural Affiliation; N4=Derogation of Groups Not Considered to Be Part of the Nation; N5 = Idealization of the Nation; N6=An Uncritical Acceptance of National, State, and Political Authorities; N7 = Other.)

Suppression of Ambivalent Attitudes toward the Nation has two peaks on the timeline: the first was on January 28th when the epidemic outbroke in China and the western world started to criticize China's performance; another fell in the period when COVID19 had been controlled in China but had just broken out in other countries.

As for Derogation of Groups not Considered to Be Part of the Nation, it reached its peak at the beginning of April. Feeling of National Superiority appeared on February 19th, rose after March 8th, and remained relatively common. However, The Inclination to Define One's Own Group by Criteria of Descent, Race, Cultural Affiliation was less frequently identified. Overall, nationalism rose rapidly once COVID-19 had been controlled in China but broke out in other countries. The trend remains to be stable despite the declination of pandemic in those foreign settings afterwards.

\section{Semantic Analysis of the suppression of Ambivalent Attitudes toward the Nation and Feeling of National Superiority}

Figures 3 and 4 represents the semantic network of comments that displays the dynamics of The Suppression of Ambivalent Attitudes toward the Nation and Feeling of National Superiority during the COVID-19 outbreak. Words such as China, US, and nation were frequently mentioned. Also, words relevant to nation-state (e.g., Denmark, overseas, come back and motherland) were prominent, which verifies the importance of nation-state as a political identity object.

However, only the discourse of The Suppression of Ambivalent Attitudes toward the Nation in the orange and purple subfigures emphasizes the national loyalty and criticizes pro-Western value and action in China. The national loyalty is also illustrated in the green subfigure and is related to the refutation of reproachful voices that China 


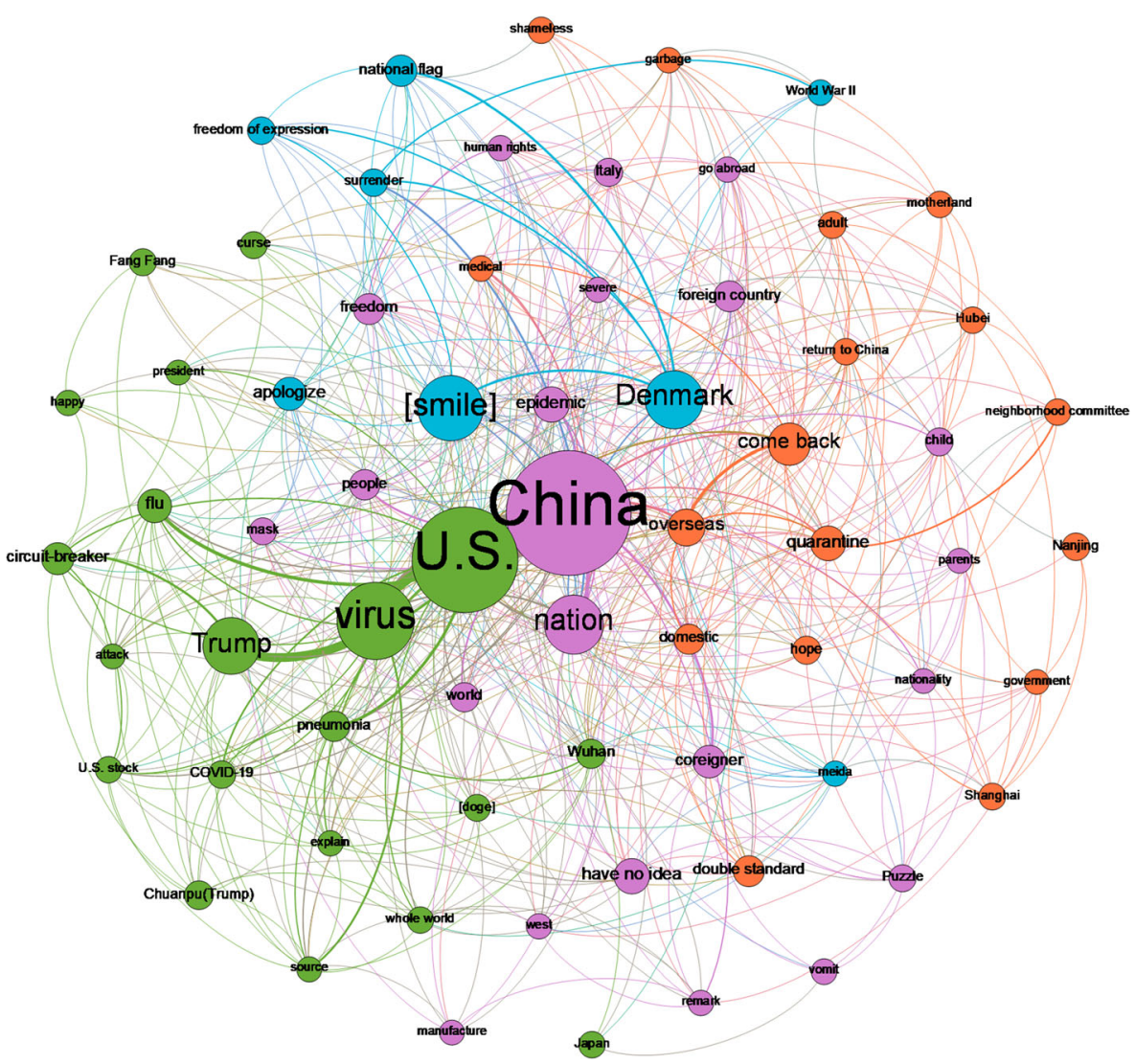

Fig. 3 Semantic network of the suppression of ambivalent attitudes toward the nation during the COVID-19 outbreak

should be responsible for the epidemic. The blue subgraph is about the anger towards Denmark's insult to Chinese national flags. ${ }^{5}$

The green, purple, and blue subgraphs are most prominent in Fig. 4. The purple one signifies the proud of China's victory in fighting against COVID-19 and its fulfillment of international responsibility as a competent country in providing assistance for other countries. For example, when one WHO expert said he hoped to be treated in China if infected, a netizen commented with pride: "China showed strong and executive power in the pandemic. It let the world reevaluate China!'. A representative comment of the green part contains critique and mockery of the U.S. ineffective COVID-19 mitigation policies. It compares it with the situation in China, claiming "It took only two months for China to control the epidemic, and less than one month for the United States to be completely under control". The blue subgraph involves discourse of Europe and Japan's puzzling mitigation strategies.

\footnotetext{
${ }^{5}$ The [smile] emoji generally represents ironic and negative emotion on social media in China. For more interesting details, see [46]. Dominant meanings of facial emoji: Insights from Chinese consumers and comparison with meanings from internet resources. Food Quality and Preference, 62, 275-283.
} 


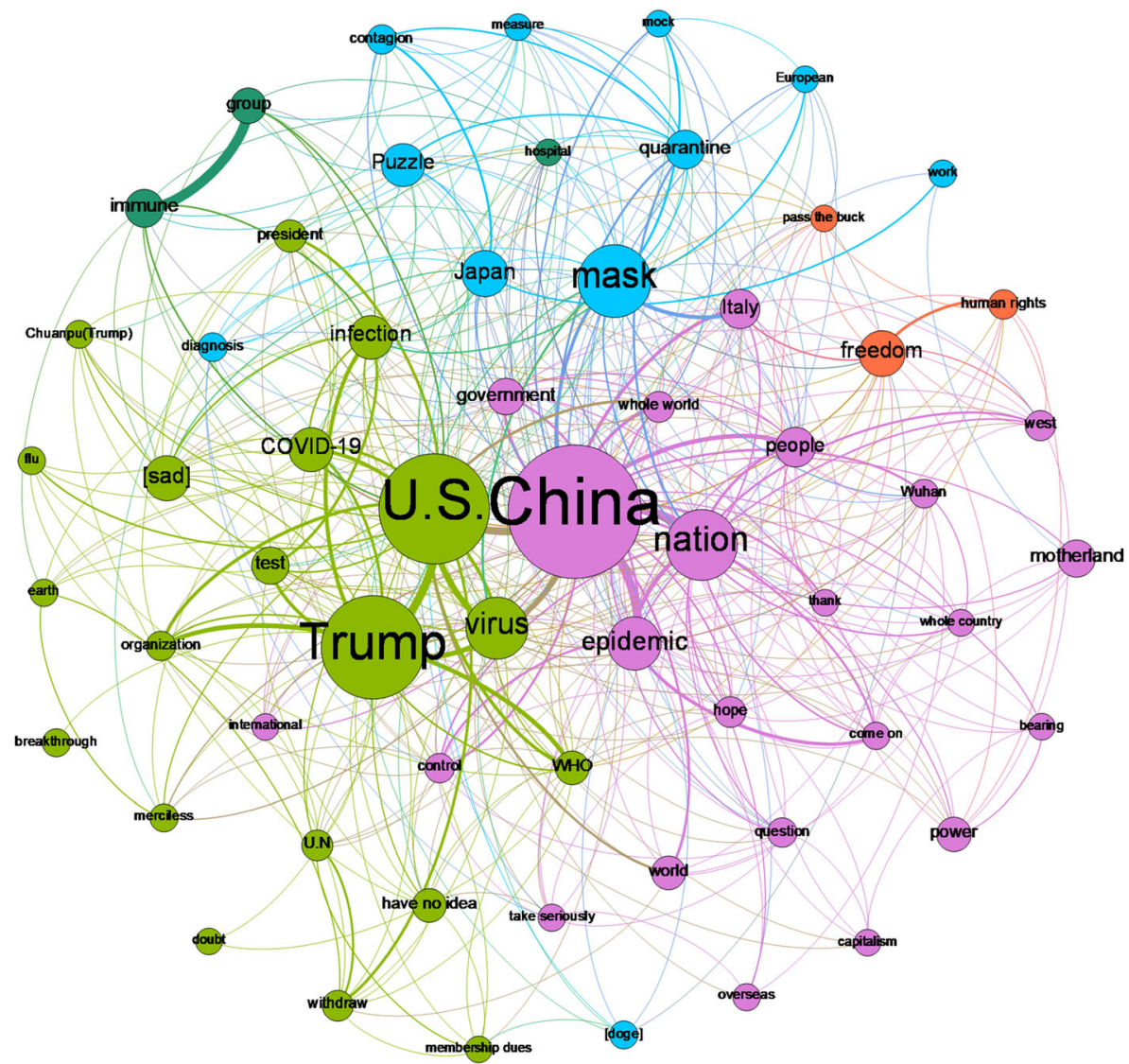

Fig. 4 Semantic network of feeling of national superiority during the COVID-19 outbreak

\section{Chinese Nationalism in the Context of Anti-Globalization Versus Pro-Globalization}

The last crucial question in our study is how attitudes to globalization is related to Chinese nationalism during the COVID-19 period. Firstly, a Chi-square test was conducted to investigate whether the pro-globalization or anti-globalization orientations in different events influence the expression of nationalism in netizens' comments. The results in Table 4 suggest that the public were more likely to express nationalism within anti-globalization issues, which rejected $\mathrm{H} 1$.

However, the cross analysis of globalization (Events) and categories of nationalism revealed other significant findings. Specifically, among all the categories, the Suppresses Ambivalent Attitudes toward the Nation stimulated by anti-globalization orientation and the Feelings of National Superiority stimulated by pro-globalization events were the most popular expression, with the proportion of $26.41 \%$ and $21.00 \%$ respectively. Also, it is noteworthy that the former feeling is more likely to be expressed in the context of anti-globalization, while that latter in the context of pro-globalization.

Chi-square test was also conducted to see the association among different characteristics of globalization and those of nationalism in comments. 


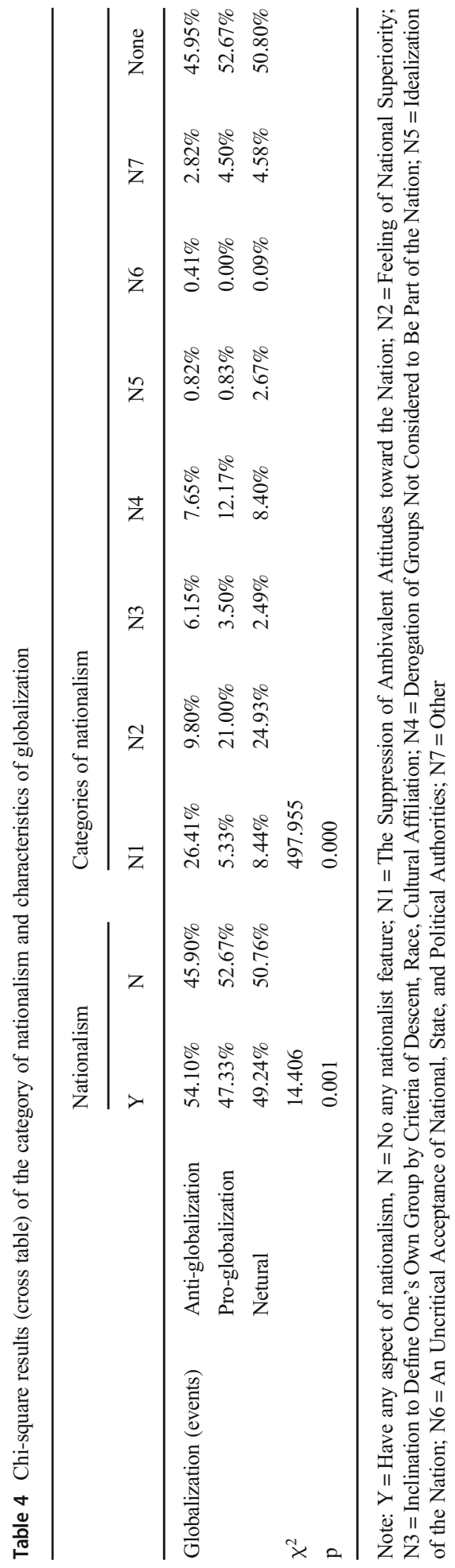




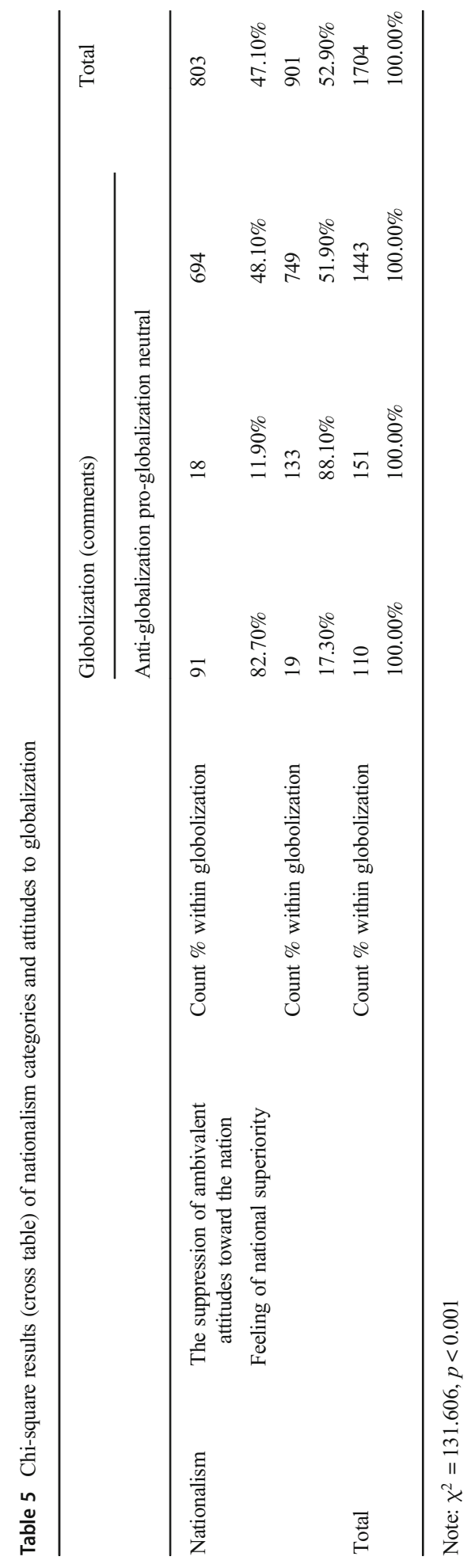


The results in Table 5 suggest that the attitudes of Anti-globalization is always accompanied by the Suppression of Ambivalent Attitudes toward the Nation. $82.70 \%$ of the Comments which express Anti-globalization exhibits the Suppression of Ambivalent Attitudes toward the Nation. Moreover, the attitudes of Pro-globalization and Feeling of National Superiority are usually expressed together.

We found that nationalism that Suppresses Ambivalent Attitudes toward the Nation doesn't advocate international communication and trade transportation, which serves as the underlying cause of its anti-globalization attitude. The typical comments include "When other countries prohibit us from entering their countries, you (foreigners) said you can understand. But why did you criticize our government when we ban foreigners from entering China. Why don't we have right to prevent virus importation?" "No mask should be exported to the United State until it apologizes for its deed." "I have written down all the countries which were not friendly to China during this period in a small notebook, and I won't visit these places in the future." In supporting the travel ban, calling for an end to international aids, and deciding not going abroad, these comments expressed the attitudes of anti-globalization. In fact, these feelings are caused by the specific type of nationalism, the Suppression of Ambivalent Attitudes toward the Nation, as counterattacks to foreign criticism that accuses China of spreading the COVID-19 pandemic. Hence, Suppression of Ambivalent Attitudes toward the Nation mediates the influence of international events on attitudes to anti-globalization.

Meanwhile, Feeling of National Superiority has led to a pro-globalization attitude. For example, one typical comment voiced supporting for the 20 million dollars donation China contributed to WHO: "I'm really proud of living in such a responsible country". This claim manifests the feeling of superiority that China is able to have a positive influence on fighting global pandemic and serve in the leading position in international affairs. Besides, other comments like "Chinese are always grateful! It practiced the moral principle our parents usually taught us 'little help brings much return"” which culturally emphasizes support for China's global responsibility. This comment was responded to a news in which Italian Foreign Minister said China gave Italy 100 times mask back. Based on that, Feeling of National superiority in morality made some Chinese express their support for aiding other countries in fighting against epidemic. Apart from being proud of China, some comments also criticized other countries' behavior such as Germany's block of masks headed for Switzerland. In fact, these criticisms that support globalization are full of irony with a sense of superiority that China has better assumed its international obligations during the pandemic.

\section{Discussion and Conclusion}

Most existing research discusses the nationalism of political authority in the relationship between Chinese and foreign groups in conflicting contexts, but little research has been conducted to investigate more fluid, detailed and nuanced aspects of nationalism, and how they are related to globalization in the context of global crisis. In this paper, we helped build blocks to answer this open-ended question by characterizing the comments made on social media in China with regard to international events during the COVID-19 pandemic. In doing so, we were able to collect representative data from Weibo. As such, we not only studied how issue-topics of international COVID-19 
events influenced the categories of nationalism but also analyzed the discourse of Feeling of National Superiority and the Suppression of Ambivalent Attitudes toward the Nation. Our finding suggest that Feeling of National Superiority reflected the pride of Chinese which was simply based on China's better performance than other countries in fighting against COVID-19, while the Suppression of Ambivalent Attitudes toward the Nation was mainly stimulated by external threats and was displayed as refuting or counterattacking other countries' criticism or stigmatization.

In addition, the findings also suggest that nationalism triggered by global crisis is not destined for undermining global order. Nationalism based on the Suppression of Ambivalent Attitudes toward the Nation is related to anti-globalization, while nationalism based on a Feeling of National Superiority does not pose a threat to globalization but is more likely to direct to pro-globalization. The former is a counterattack against the criticism and stigmatization of the nation, while the latter derives from the international comparison based on the nation's international status. Our research revealed two paths for nationalism to respond to external shocks: one is a counterattack response to external threats and repression, which resorts to cutting off communication and international connections as retaliation; and the other is a comparative response to global competition, which stimulates Feeling of National Superiority (i.e., that China did better than other countries in battling COVID-19 and acquired higher international status than its major competitors). We believe that with more time, we could have taken a mixed approach to further investigate the psychological mechanism of responses to these two exogenous shocks and maybe other types of external shocks.

As an outcome of the interaction between macro-political events and micro-political psychology, the rise of nationalist sentiment is not only the result of long-term education and propagation but also tremendously affected by short-term exogenous shocks. ${ }^{6}$ The context of the current popular nationalism is deeply rooted in a globally connected world, and there has also been a political emulation effect during the epidemic [37]. Therefore, researchers should pay more attention to the different awakening effects of exogenous shocks to nationalism. Our research reveals that the political consequences of global crisis depend not only on whether nationalism rises but also on how it evolves. In other words, the nationalism was impacted not only by the nation's unique history situated in the international environment relative to different countries but also by the dissemination of crisis information and subsequently the public mind in crucial events. In the context of China, this sense of national superiority supports more active participation in global governance and is based on China's success in fighting the epidemic. This conclusion is supported not only by Fig. 1 and Table 4 but also by Fig. 2 which shows that nationalism rose once the epidemic had been controlled in China and had just broken out overseas. "Timely donation, timely help! Great power model!" represents a good example of comments exhibiting Feeling of National Superiority and supporting more active participation in global governance. A further implication of these findings is that amid global crisis, benign domestic

\footnotetext{
${ }^{6}$ For long-term effects, see: [23]. The effect of education on nationalism and ethnic exclusionism: An international comparison. Political psychology, 24 (2), 313-343. For the impact of short-term events see Cairns, Christopher, and Allen Carlson. 2016. Real-world islands in a social media sea: nationalism and censorship on Weibo during the 2012 Diaoyu/Senkaku crisis. The China Quarterly, 225, 23-49.
} 
governance can lead to positive external results, and active international cooperation could, in turn, shape a good domestic environment.

Our corpus is limited to the social media data of 164 of the most commonly discussed international COVID-19 events. However, we argue that our focus is investigating different aspects of nationalism per issue-topic. Our findings are significant in that despite the public's social media use was already nearly universal in 2018, during the period of COVID-19 home quarantine, more and most people discussed public events on social media and made our data richer and more representative. In addition, our analysis is limited to the 5046 most popular comments on these events. Still, we argue that because of platform restrictions and time limitations, we could not acquire a full sample and manually code such big corpus. Future research can improve the method using supervised machine learning to code a larger sample. Moreover, it is difficult to determine whether there is a causal relationship between external events and specific types of nationalism in our analysis. However, considering the natural corresponding relationship between comments and posts of related events on Weibo, our data implies the causal effects of the COVID-19 events on Weibo comments.

Finally, regarding the influence of nationalism on global order, the representativeness of Chinese nationalism may be questioned. This is particularly true considering the issue of Internet censorship in China, which may lead to a lack of generalization of our results. However, the logic of the Chinese government's censorship is to avoid collective action and give less attention to criticism [51], instead of stimulating nationalism to enhance ideological control and political legitimacy. This claim could be elucidated in studies how the expression of nationalism on Chinese Internet often poses threat to government on foreign issues $[19,82]$. No research has proved that the censorship can stimulate the expression of nationalism content. In fact, the number of two main types of nationalism in this study are similar and both imply critics to the government. Existing research has established that Chinese nationalism will not be a major threat for global order. In this sense, issues like what kinds of foreign policy that such nationalism will lead to and whether social media information for global crisis has been censored and manipulated ought to be discussed in future research.

\section{References}

1. Adorno, T.W., E. Frenkel-Brunswik, D.J. Levinson, and R.N. Sanford. 1950. The authoritarian personality. New York: Norton.

2. Ahmad, Ehtisham. 2020. Multilevel responses to risks, shocks and pandemics: Lessons from the evolving Chinese governance model. Journal of Chinese Governance. https://oi.org/10.1080/ 23812346.2020 .1813395$.

3. Albertoni, N., and C. Wise. 2020. International trade norms in the age of Covid-19 nationalism on the rise? Fudan Journal of the Humanities and Social Sciences 14: 41-66. https://doi.org/10.1007/s40647020-00288-1.

4. Allen, J., N. Burns, L. Garrett, R.N. Haass, G.J. Ikenberry, K. Mahbubani, et al. 2020. How the world will look after the coronavirus pandemic. Foreign Policy 20: 2020 Retrieved from: https://foreignpolicy. com/2020/03/20/world-order-after-coroanvirus-pandemic/.

5. Allport, G.W. 1995. The nature of prejudice. 25th ed. New York: Addison-Wesley.

6. Anderson, B. 2006. Imagined communities: Reflections on the origin and spread of nationalism. London: Verso. 
7. Baike, J. (2005). Chinese internet nationalism in the era of globalization. The Journal of Modern Chinese Literature 34:255-278.

8. Balibar, E., I.M. Wallerstein, and S.R.I. Wallerstein. 1991. Race, nation, class: Ambiguous identities. London: Verso.

9. Bașkan, F. 2006. Globalization and nationalism: The nationalist action Party of Turkey. Nationalism and Ethnic Politics 12 (1): 83-105.

10. Bieber, Florian. 2020. Debating nationalism. The global spread of nations. London: Bloomsbury.

11. Blank, Thomas, and Peter Schmidt. 2003. National identity in a united Germany: Nationalism or patriotism? An empirical test with representative data. Political Psychology 24: 289-311.

12. Bonikowski, B. 2017. Ethno-nationalist populism and the mobilization of collective resentment. The British Journal of Sociology 68: S181-S213.

13. Boylan, B.M., J. McBeath, and B. Wang. 2020. US-China relations: Nationalism, the trade war, and COVID-19. Fudan Journal of the Humanities and Social Sciences 14: 23-40. https://doi.org/10.1007/ s40647-020-00302-6.

14. Brand, U. 2005. Order and regulation: Global governance as a hegemonic discourse of international politics? Review of International Political Economy 12 (1): 155-176.

15. Breuilly, J. 1982. Nationalism and the State. Manchester University: Manchester University Press.

16. Brittingham, M.A. 2007. The "role" of nationalism in Chinese foreign policy: A reactive model of nationalism \& conflict. Journal of Chinese Political Science 12 (2): 147-166.

17. Brown, D. 1999. Are there good and bad nationalisms? Nations and Nationalism 5: 281-302.

18. Brown, R. 2011. Prejudice: Its social psychology. Hoboken: Wiley.

19. Cairns, C., and A. Carlson. 2016. Real-world islands in a social media sea: Nationalism and censorship on Weibo during the 2012 Diaoyu/Senkaku crisis. The China Quarterly 225: 23-49.

20. Callahan, W.A. 2004. National insecurities: Humiliation, salvation, and Chinese nationalism. Alternatives 29 (2): 199-218.

21. Chan, C.P., and B. Bridges. 2006. China, Japan, and the clash of nationalisms. Asian Perspective 30 (1): $127-156$.

22. Chang, Y. 2020. The post-pandemic world: Between constitutionalized and authoritarian orders China's narrative-power play in the pandemic era. Journal of Chinese Political Science. https://doi.org/ 10.1007/s11366-020-09695-3.

23. Coenders, M., \& Scheepers, P. 2003. The effect of education on nationalism and ethnic exclusionism: An international comparison. Political psychology 24:313-343.

24. Conversi, D. 2012. Modernism and nationalism. Journal of Political Ideologies 17 (1): 13-34.

25. Danowski, J.A. 1993. Network analysis of message content. Progress in Communication Sciences 12: 198-221.

26. Darr, Benjamin Joseph 2011. Nationalism and state legitimation in contemporary China. PhD (Doctor of Philosophy) thesis, University of Iowa.

27. Davidov, E. 2009. Measurement equivalence of nationalism and constructive patriotism in the ISSP: 34 countries in a comparative perspective. Political Analysis 17 (1): 64-82.

28. Devakumar, D., G. Shannon, S.S. Bhopal, and I. Abubakar. 2020. Racism and discrimination in COVID19 responses. The Lancet 395 (10231): 1194.

29. Doerfel, M. L. 1998. What constitutes semantic network analysis? A comparison of research and methodologies. Connections 21:16-26.

30. Duara, P. 1993. De-constructing the Chinese nation. The Australian Journal of Chinese Affairs 30: 1-26.

31. Eriksen, T.H. 2007. Nationalism and the internet. Nations and Nationalism 13 (1): 1-17.

32. Fewsmith, J., and S. Rosen. 2001. The domestic context of Chinese foreign policy: Does "public opinion" matter? In The making of Chinese foreign and security policy in the era of reform, 19782000, ed. David M. Lampton, 151-187. Stanford: Stanford University Press.

33. Fukuyama, Francis. 2020. The pandemic and political order. Foreign Affairs 99 (4): 26-32.

34. Garrett, B. 2001. China faces, debates, the contradictions of globalization. Asian Survey 41 (3): $409-427$.

35. Gellner, E. (2008). Nations and nationalism. Ithaca, New York: Cornell University Press.

36. Giddens, A. 1998. The Third Way: The Renewal of Social Democracy. Cambridge: Polity Press.

37. Givens, J.W., and E. Mistur. 2020. The sincerest form of flattery: Nationalist emulation during the COVID19 pandemic. Journal of Chinese Political Science. https://doi.org/10.1007/s11366-020-09702-7.

38. Goode, J. P., Stroup, D. R., \& Gaufman, E. 2020. Nationalities Papers 1-26.

39. Gregor, A.J., and M.H. Chang. 1979. Nazionalfascismo and the revolutionary nationalism of Sun Yatsen. The Journal of Asian Studies 39: 21-37.

40. Gries, P.H., Q. Zhang, H.M. Crowson, and H. Cai. 2011. Patriotism, nationalism and China's US policy: Structures and consequences of Chinese national identity. The China Quarterly 205: 1-17. 
41. Hastings, A. 1997. The construction of nationhood: Ethnicity, religion and nationalism. New York: Cambridge University Press.

42. He, Y. 2007. History, Chinese nationalism and the emerging Sino-Japanese conflict. Journal of Contemporary China 16 (50): 1-24.

43. He, B., and Y.J. Guo. 2018. Nationalism, national identity and democratization in China. New York: Routledge.

44. Huang, Q. 2020. The pandemic and the transformation of liberal international order. Journal of Chinese Political Science. https://doi.org/10.1007/s11366-020-09698-0.

45. Hughes, C.R. 2006. Chinese nationalism in the global era. London: Routledge.

46. Jaeger, S. R., \& Ares, G. 2017. Dominant meanings of facial emoji: Insights from Chinese consumers and comparison with meanings from internet resources. Food Quality and Preference 62: 275-283.

47. Jaworsky, B.N., and R. Qiaoan. 2020. The politics of blaming: The narrative battle between China and the US over COVID-19. Journal of Chinese Political Science. https://doi.org/10.1007/s11366-02009690-8.

48. Hechter, M. 2000. Containing nationalism. New York: Oxford University Press.

49. Held, D., McGrew, A., Goldblatt, D., \& Perraton, J. 2000. Rethinking globalization: An analytical framework. In D. Held and A. McGrew (Eds.), The global transformations reader: An introduction to the globalization debate (pp. 54-60). Cambridge: Polity Press.

50. Kelman, H.C. 1997. Nationalism, patriotism, and national identity: Social-psychological dimensions. In Patriotism in the lives of individuals and nations, ed. D. Bar-Tal and E. Staub, 165-189. Chicago: Nelson-Hall.

51. King, G., J. Pan, and M.E. Roberts. 2013. How censorship in China allows government criticism but silences collective expression. American Political Science Review 107 (02): 326-343.

52. Kosterman, R., and S. Feshbach. 1989. Toward a measure of patriotic and nationalistic attitudes. Political Psychology 10: 257-273.

53. Laato, S., Najmul Islam, A. K. M., Nazrul Islam, M., \& Whelan, E. 2020. Why do People Share Misinformation during the COVID-19 Pandemic? arXiv, arXiv-2004. Retrieved from: https://www. researchgate.net/profile/Samuli_Laato/publication/340826868_Why_do_People_Share_ Misinformation during the COVID-19 Pandemic/links/5ea6ec11a6fdccd79458̄186̄/Why-do-PeopleShare-Misinformation-during-the-COVID-19-Pandemic.pdf.

54. Li, H. 2008. Branding Chinese products: Between nationalism and transnationalism. International Journal of Communication 2: 38.

55. Li, H. 2016. How to understand nationalism in China?: An analysis of "D8 expedition". Chinese Journal of Journalism and Communication 38 (11): 91-113.

56. Linz, J.J. 1993. State building and nation building. European Review 1 (4): 355-369.

57. Liu, S.-D. 2010. Networking anti-Japanese protests: Popular sovereignty reasserted since 2005. In Online Chinese nationalism and China's bilateral relations, ed. S. Shen and S. Breslin, 73-90. Lanham, MD: Lexington Books.

58. Makarychev, A., and T. Romashko. 2020. Precarious sovereignty in a post-liberal Europe: The COVID19 emergency in Estonia and Finland. Chinese Political Science Review 6: 63-85. https://doi.org/10. 1007/s41111-020-00165-y.

59. Malešević, S. 2019. Grounded nationalisms: A sociological analysis. New York: Cambridge University Press.

60. McFarland, S.G. 2005. On the eve of war: Authoritarianism, social dominance, and American students' attitudes toward attacking Iraq. Personality and Social Psychology Bulletin 31 (3): 360-367.

61. Meloen, J.D. 1999. The political culture of state authoritarianism. In Political psychology: Cultural and cross-cultural perspectives, ed. S. Renshon and J. Duckitt, 108-127. London: Macmillan.

62. Pan, G., and A. Korolev. 2021. The struggle for certainty: Ontological security, the rise of nationalism, and Australia-China tensions after COVID-19. Journal of Chinese Political Science. https://doi.org/10. 1007/s11366-020-09710-7.

63. Qingguo, J. 2005. Disrespect and distrust: The external origins of contemporary Chinese nationalism. Journal of Contemporary China 14 (42): 11-21.

64. Rokeach, M. 1960. The open and closed mind: Investigations into the nature of belief systems and personality systems. New York: Basic Books.

65. Salvati, E. 2020. Crisis and intergovernmental retrenchment in the European Union? Framing the EU's answer to the COVID-19 pandemic. Chinese Political Science Review 6: 1-19. https://doi.org/10.1007/ s41111-020-00171-0.

66. Schattle, H. 2008. Education for global citizenship: Illustrations of ideological pluralism and adaptation. Journal of Political Ideologies 13 (1): 73-94. 
67. Schatz, R.T., E. Staub, and H. Lavine. 1999. On the varieties of national attachment: Blind versus constructive patriotism. Political Psychology 20: 151-174.

68. Scholte, J.A. 2005. Globalization: A critical introduction. Basingstoke: Macmillan International Higher Education.

69. Shirk, S.L. 2007. China: Fragile superpower. Oxford: Oxford University Press.

70. Smith, A.D. 2000. The nation in history: Historiographical debates about ethnicity and nationalism. Hanover: UPNE.

71. Spohr, D. 2017. Fake news and ideological polarization: Filter bubbles and selective exposure on social media. Business Information Review 34 (3): 150-160.

72. Steger, M.B. 2005. Ideologies of globalization. Journal of Political Ideologies 10 (1): 11-30.

73. Van den Berghe, P.L. 1978. Race and ethnicity: A sociobiological perspective. Ethnic and Racial Studies 1 (4): 401-411.

74. Wang, J. 2006. The politics of goods: A case study of consumer nationalism and media discourse in contemporary China. Asian Journal of Communication 16 (02): 187-206.

75. Wang, Z. 2021. From crisis to nationalism? The conditioned effects of the COVID-19 crisis on neonationalism in Europe. Chinese Political Science Review 6: 20-39. https://doi.org/10.1007/s41111-02000169-8.

76. Wang, Z., and Z. Sun. 2020. From globalization to regionalization: The United States, China, and the post-Covid-19 world economic order. Journal of Chinese Political Science. https://doi.org/10.1007/ s11366-020-09706-3.

77. Yang, G. 2009. The power of the internet in China: Citizen activism online. New York: Columbia University Press.

78. Yang, Y., and X. Chen. 2020. Globalism or nationalism? The paradox of Chinese official discourse in the context of the COVID-19 outbreak. Journal of Chinese Political Science. https://doi.org/10.1007/ s11366-020-09697-1.

79. Yang, L., and Y. Zheng. 2012. Fen qings (angry youth) in contemporary China. Journal of Contemporary China 21 (76): 637-653.

80. Youde, J. March 23, 2020. How 'medical Nationalism'is undermining the fight against the coronavirus pandemic. World Politics Review. Retrieved from: https:/www.worldpoliticsreview.com/articles/28623/ how-medical-nationalism-is-undermining-the-fight-against-the-coronavirus-pandemic.

81. Zhang, X. 2001. The making of the Post-Tiananmen intellectual field: A critical overview. In Whither China? Intellectual politics in contemporary China, ed. Zhang, 1-75. Durham: Duke University Press.

82. Zhang, Y., J. Liu, and J.R. Wen. 2018. Nationalism on Weibo: Towards a multifaceted understanding of Chinese nationalism. The China Quarterly 235: 758-783.

83. Zhang, X., W. Luo, and J. Zhu. 2021. Top-down and bottom-up lockdown: Evidence from COVID-19 prevention and control in China. Journal of Chinese Political Science. https://doi.org/10.1007/s11366020-09711-6.

84. Zhao, S. 1998. A state-led nationalism: The patriotic education campaign in post-Tiananmen China. Communist and Post-Communist Studies 31 (3): 287-302.

85. Zhao, S. 2000. Chinese nationalism and its international orientations. Political Science Quarterly 115 (1): $1-33$.

86. Zhao, S. 2004. A nation-state by construction: Dynamics of modern Chinese nationalism. Stanford: Stanford University Press.

87. Zhao, X. 2020. A discourse analysis of quotidian expressions of nationalism during the COVID-19 pandemic in Chinese cyberspace. Journal of Chinese Political Science. https://doi.org/10.1007/s11366020-09692-6.

88. Zheng, Y., and Y. Zheng. 1999. Discovering Chinese nationalism in China: Modernization, identity, and international relations. New York: Cambridge University Press.

89. Zhimin, C. 2005. Nationalism, internationalism and Chinese foreign policy. Journal of Contemporary China 14 (42): 35-53.

Zhenyu Wang is a Ph.D. Candidate of Fudan Journalism School. He is also the co-founder of the Lawftech Tech Company, an AI start-up focusing on social decision support. His research interests include: Chinese nationalism, Data Science, Chinese politics, and Digital media.

Yuzhou Tao is a Ph.D. candidate of Fudan Journalism School. Her research interest covers mass communication, health communication, and social media. 